\title{
Personal and Socio-Economic Characteristics of the Rural Women of Udaipur District (Raj.)
}

\author{
Sonu Mertiya ${ }^{1}$, Rajshree Upadhyay ${ }^{2}$ \\ College of Home Science, MPUAT, Udaipur (Raj.)
}

\begin{abstract}
The present paper aims at highlighting the personal and socio-economic characteristics of rural women. The study was conducted in Udaipur district of Rajasthan with a total sample of 100 rural women. The major findings reveal that Socio personal variables like age, marital status, occupation, education, caste, family size and type, organizational membership, land holding, housing, livestock ownership dwelling, media ownership, extension contact and their socio-economic status were found to be personal and socioeconomic characteristics of the rural women.
\end{abstract}

Keywords: Rural Women

\section{Introduction}

Women entrepreneurship has been recognized as an important source of economic growth. By establishing their new venture women entrepreneurs generate new jobs for themselves and others and also provide society with different solutions to management, organization and business problems. Women entrepreneurs often face genderbased barriers to starting and growing their businesses, like discriminatory property, matrimonial and inheritance laws and cultural practices; lack of access to formal finance mechanisms limited mobility and access to information and networks, etc. Rural women are more vulnerable as they do not get enough opportunity to make use of their economic potential. Thus it is must to bring rural women in the mainstream of entrepreneurship development. Women's entrepreneurship can make a particularly strong contribution to the economic well-being of the family and communities, poverty reduction and women's empowerment. Thus, governments across the world as well as various developmental organizations are actively assisting and promoting women entrepreneurs through various schemes, incentives and promotional measures.

\section{Methodology}

The study was conducted in two randomly selected panchayat samities of Udaipur district i.e. Mavli and Girwa. A list of rural women belonging to both the selected panchayat samities who received entrepreneurial training at least one year before, was obtained from the officials of ICICI- Rural Self Employment Training Institute, Udaipur. From the list, 50 rural women from each panchayat samiti were selected randomly. Thus, the sample of the study comprised of 100 rural women. Data were collected with the help of personal interview schedule. Frequency was used for analysis of the data statistically.

\section{Results and Discussion}

The general information of the respondents like age, marital status, occupation, education, caste, family size and type, organizational membership, land holding, housing, livestock ownership dwelling, media ownership, extension contact and their socio- economic status,.
Age: Data in Table (1) reveals that majority of the respondents $(68 \%)$ belonged to the age group 18-30 years while rest of the respondents $(32 \%)$ were in the age group of 31-45 years.

Marital Status: Table (1)portrays that majority of the respondents $(62 \%)$ were married, while 32 per cent respondents were unmarried and 6 per cent were widow.

Occupation: Table (1) portrays that more than half of the respondents $(51 \%)$ had farming as their occupation, 22 per cent involved in service sector, 19 per cent farm labor and only 8 per cent were non-wage earners.

Education: Education is one of the most important determinants of a person's social status. Regarding educational level of the respondents. Table (1) indicates that 40 per cent respondents were illiterate. Among the literates, 30 per cent were able to read and write, 21 per cent were educated up to primary school and only 9 per cent were educated up to middle class.

Table 1: Distribution of the respondents by their personal variables

$\mathrm{n}=100$

\begin{tabular}{|c|c|c|}
\hline S. No. & Personal variables & $\mathrm{f} / \%$ \\
\hline \multirow[t]{5}{*}{$\mathbf{A}$} & \multicolumn{2}{|l|}{ Age } \\
\hline & 1. $18-30$ yrs. & 68 \\
\hline & 2. $31-45$ yrs. & 32 \\
\hline & 3. $46-60$ yrs. & 0 \\
\hline & 4. Above 60 yrs. & 0 \\
\hline \multirow[t]{5}{*}{ B } & \multicolumn{2}{|l|}{ Marital Status } \\
\hline & 1. Unmarried & 32 \\
\hline & 2. Married & 62 \\
\hline & 3. Widow & 6 \\
\hline & 4. $\quad$ Divorced & 0 \\
\hline \multirow[t]{5}{*}{$\mathbf{C}$} & \multicolumn{2}{|l|}{ Occupation } \\
\hline & 1. Non-wage Earner & 8 \\
\hline & 2. $\quad$ Farm labor & 19 \\
\hline & 3. $\quad$ Farming & 51 \\
\hline & 4. $\quad$ Service sector & 22 \\
\hline D & \multicolumn{2}{|l|}{ Education } \\
\hline & 1. $\quad$ Illiterate & 40 \\
\hline & 2. $\quad$ Read/Write & 30 \\
\hline & 3. $\quad$ Primary school & 21 \\
\hline & 4. Middle school & 9 \\
\hline
\end{tabular}




\section{International Journal of Science and Research (IJSR) \\ ISSN (Online): 2319-7064}

Index Copernicus Value (2015): 78.96 | Impact Factor (2015): 6.391

Caste: Data in the table reveals that 41 per cent of the respondents belonged to upper middle caste, while 28 and 24 per cent belonged to OBC and upper caste respectively and only 7 per cent of the respondents were from SC/ST category.

Family Structure: Visualization of Table (2) indicates that majority of the respondents $(75 \%)$ were from joint family and rest of the respondents $(25 \%)$ had nuclear family. Regarding the size of family, table further reveals that 48 per cent of the respondents had medium size family, one third respondents $(33 \%)$ had large size family, and 19 per cent had small size family.

Organizational Membership: Data presented in Table (2) show that most of the respondents (94\%) had no organizational membership while only 6 per cent of the respondents were member of a self-help group.

Table 2: Distribution of the respondents on the basis of social variables, $\mathrm{n}=100$

\begin{tabular}{|c|c|c|}
\hline S. No. & Social variables & $\mathrm{f} / \%$ \\
\hline \multirow[t]{5}{*}{$\mathbf{A}$} & \multicolumn{2}{|l|}{ Caste } \\
\hline & 1. $\mathrm{SC} / \mathrm{ST}$ & 7 \\
\hline & 2. $\mathrm{OBC}$ & 28 \\
\hline & 3. Upper middle class & 41 \\
\hline & 4. Upper caste & 24 \\
\hline \multirow{4}{*}{$\begin{array}{l}\text { B } \\
\text { a) }\end{array}$} & \multicolumn{2}{|l|}{ Family structure } \\
\hline & \multicolumn{2}{|l|}{ Family type } \\
\hline & 1. Nuclear & 25 \\
\hline & 2. Joint & 75 \\
\hline \multirow[t]{4}{*}{ b) } & \multicolumn{2}{|l|}{ Family size } \\
\hline & 1. Small (upto 4) & 19 \\
\hline & 2. Medium (upto 5-8) & 48 \\
\hline & 3. $\quad$ Large ( 8 and above) & 33 \\
\hline \multirow[t]{6}{*}{ C } & \multicolumn{2}{|l|}{ Organizational membership } \\
\hline & 1. Member of formal organization & 6 \\
\hline & 2. Office bearer of formal organization & 0 \\
\hline & 3. Member of non-formal organization & 0 \\
\hline & 4. Office bearer of non-formal organization & 0 \\
\hline & 5. No membership & 94 \\
\hline
\end{tabular}

Land Holding: Perusal of data in Table (3) show that 46 per cent respondents had 1.0 to 2.5 acres of land, one third respondents $(33 \%)$ had 2.6 to 5.0 acres, while few respondents were in the category of 5.1 to 10 acres of land $(6 \%)$ and more than 10 acres of land $(5 \%)$.

Housing: Looking into the housing of the respondents, more than half of the respondents $(57 \%)$ had pucca house whereas 28 per cent had kutcha and 15 per cent respondents had mixed house.

Livestock ownership: It is evident from Table (3) that 49 per cent respondents had large herd size while 29 and 22 per cent of the respondents owned medium and small herd size respectively.

Dwelling: Data in the table also reveals that majority of the respondents $(61 \%)$ had open dwelling for their livestock, 36 per cent of the respondents had kutcha dwelling and only 3 per cent had pucca dwelling for their livestock.
Table 3: Distribution of the respondents on the basis of their economic variables

$$
n=100
$$

\begin{tabular}{|l|l|c|}
\hline S. No & Economic variables & f/\% \\
\hline A & Land Holding & 10 \\
\cline { 2 - 3 } & No land & 46 \\
\cline { 2 - 3 } & 1.0 to 2.5 acres & 33 \\
\cline { 2 - 3 } & 2.6 to 5.0 acres & 6 \\
\cline { 2 - 3 } & 5.1 to 10.0 acres & 5 \\
\cline { 2 - 3 } & More than 10 acres & 28 \\
\hline B & Housing & 15 \\
\cline { 2 - 3 } & Kutcha house & 57 \\
\cline { 2 - 3 } & Mixed house (Partially kutcha + pakka house) \\
\cline { 2 - 3 } & Pakka house & 22 \\
\hline C & Livestock ownership & 49 \\
\cline { 2 - 3 } & Small herd size & 61 \\
\cline { 2 - 3 } & Medium herd size & 36 \\
\cline { 2 - 3 } & Large herd size & \\
\hline D & Dwelling & \\
\cline { 2 - 3 } & Open/Nil & \\
\cline { 2 - 3 } & Thatched / Kutcha & \\
\cline { 2 - 3 } & Pakka & \\
\hline
\end{tabular}

Media ownership: Data in theTable (4) reveals that 45 per cent of the respondents owned television, 34 per cent respondents subscribed newspaper/ magazines, 13 per cent respondents had radio and 8 per cent respondents had no ownership of media.

Table 4: Distribution of the respondents on the basis of their Media ownership and entertainment, $\mathbf{n}=\mathbf{1 0 0}$

\begin{tabular}{|c|l|c|}
\hline S. No. & \multicolumn{1}{|c|}{ Media ownership } & f/\% \\
\hline A. & Nil & 8 \\
\hline B. & Newspaper / magazines & 34 \\
\hline C. & Radio/transistor & 13 \\
\hline D. & Television & 45 \\
\hline
\end{tabular}

Extension contact: The data in Table (5) reveals 49 per cent respondents gathered information regarding extension contact once in a month, 39 per cent once in a week, 6 per cent contacted frequently and 6 per cent had no extension contact.

Table 5: Distribution of the respondents on the basis of their Extension contact $\mathrm{n}=100$

\begin{tabular}{|c|c|c|}
\hline S. No. & Personal variables & f/\% \\
\hline A. & Frequently & 6 \\
\hline B. & Once in a week & 39 \\
\hline C. & Once in a month & 49 \\
\hline D. & Never & 6 \\
\hline
\end{tabular}

Socio economic status: On the basis of scores obtained by the respondents in the different aspects of socio-economic status scale, the respondents were categorized as having high, medium and low socio-economic status. Data in Table (6) point out that majority of the respondents (67\%) were from low socio-economic status whereas 27 per cent respondents had medium socio economic status and only 6 per cent were from high socio economic status. 


\section{International Journal of Science and Research (IJSR) \\ ISSN (Online): 2319-7064}

Index Copernicus Value (2015): 78.96 | Impact Factor (2015): 6.391

Table 6: Distribution of the respondents on the basis of their socio-economic status, $\mathrm{n}=100$

\begin{tabular}{|c|c|c|}
\hline S. No. & Socio Economic Status & f/\% \\
\hline 1 & Low & 67 \\
\hline 2 & Medium & 27 \\
\hline 3 & High & 6 \\
\hline
\end{tabular}

\section{Conclusion}

The socio-economic status of rural women belonged to low socio economic status.

\section{References}

[1] Jaiswal, A. and Patel, M.M. and Dubey, R. 2014. An Analysis of Socio-economic and Psychological Attributes of Rural Women Entrepreneur in Indore Block of Indore District Madhya Pradesh, India. International Journal of Current Microbiology and Applied Science.3: 582-85.

[2] Kumar, S., Singh, R. and Singh, Y.P.2007. Determinants of Entrepreneurial Behaviour of Dairy Farmers - A Case Study from Bareilly District of UP. Agriculture economics research review 23: 558.

[3] Lawrence, C and Ganguli, D. 2012 .Entrepreneurial Behaviour of Dairy Farmers in Tamil Nadu. Indian Research Journal on Extension Education.12 (1): 6670.

[4] Manay, S. and Farzana, C., 2000, Socio-economic characteristics of rural family. Maharashtra Journal of Extension Education. 19: 325-328.

[5] Ravi, G.K. 2007. A Study on Entrepreneurial Behavioral Characteristics of SC and ST Farmers of Gulbarga District. M. Sc. (Agri.) Thesis submitted to University of Agriculture Sciences, Dharwad.

[6] Senthamarai, G., Manoharan, M. and Singh, P. T, 1997, Socio-personal and psychological characteristics of farm women. Maharashtra Journal of Extension Education. 16: 320- 322 .

\section{Author Profile}

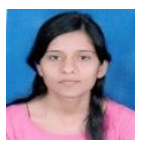

Sonu Mertiya, Master of Science (Home Science), Department of Home Science Extension \& Communication Management, College of Home Science, MPUAT, Udaipur (Raj.)

Rajshree Upadhyay (second author) is Professor and Head, Department of Home Science Extension \& Communication Management, College of Home Science, MPUAT, Udaipur (Raj.) 